University of Wollongong

Research Online

Faculty of Law, Humanities and the Arts Papers (Archive)

Faculty of Arts, Social Sciences \& Humanities

$1-1-2019$

Dynamic paths of innovation in natural resource industries in Australia and Norway since World War Two

\author{
Simon Ville \\ University of Wollongong, sville@uow.edu.au \\ Olav Wicken \\ University of Oslo, olav.wicken@tik.uio.no \\ John Dean \\ University of Wollongong, jbrd999@uowmail.edu.au
}

Follow this and additional works at: https://ro.uow.edu.au/lhapapers

Part of the Arts and Humanities Commons, and the Law Commons

Research Online is the open access institutional repository for the University of Wollongong. For further information contact the UOW Library: research-pubs@uow.edu.au 


\title{
Dynamic paths of innovation in natural resource industries in Australia and Norway since World War Two
}

\author{
Abstract \\ This paper challenges Ed Barbier's influential contribution to the resources and economic development \\ debate and extends our understanding of the process of resource-based development in two relevant \\ economies since World War Two. We argue that: the expansion of resource-based industries remained a \\ viable path of economic development in the 'contemporary era' since the 1950s; nations have modernised \\ their economies while continuing to invest in resource industries; and innovation frontiers more than \\ physical frontiers shaped the development of natural resource industries. We build our argument by \\ providing a comparative study of two successful resource-based economies, Australia and Norway. Our \\ focus is on aquaculture and offshore oil and gas, growth industries in both countries. Aquaculture is \\ renewable and of recent origin, offshore oil and gas is non-renewable but with a longer history in other \\ nations. Differences between the two nations are also discussed, particularly the narrower product \\ specialisations of Norway. In both nations and both industries, though, there are common patterns of \\ knowledge-intensive development through three stages-learning from older and imported technologies, \\ the development of national capabilities, and their exploitation overseas through internationalisation-that \\ draw upon the relationship between the resource sector and its supporting enabling sector.

\section{Disciplines} \\ Arts and Humanities | Law

\section{Publication Details} \\ Ville, S., Wicken, O. \& Dean, J. (2019). Dynamic paths of innovation in natural resource industries in \\ Australia and Norway since World War Two. Scandinavian Economic History Review, 67 (1), 90-109.
}




\section{Dynamic paths of innovation in natural resource industries in Australia and}

\section{Norway since World War Two}

\section{Abstract}

This paper challenges Ed Barbier's influential contribution to the resources and economic development debate and extends our understanding of the process of resource-based development in two relevant economies since World War Two. We argue that: the expansion of resource-based industries remained a viable path of economic development in the 'contemporary era' since the 1950s; nations have modernised their economies while continuing to invest in resource industries; and innovation frontiers more than physical frontiers shaped the development of natural resource industries. We build our argument by providing a comparative study of two successful resource-based economies, Australia and Norway. Our focus is on aquaculture and offshore oil and gas, growth industries in both countries. Aquaculture is renewable and of recent origin, offshore oil and gas is nonrenewable but with a longer history in other nations. Differences between the two nations are also discussed, particularly the narrower product specialisations of Norway. In both nations and both industries, though, there are common patterns of knowledge-intensive development through three stages - learning from older and imported technologies, the development of national capabilities, and their exploitation overseas through internationalisation - that draw upon the relationship between the resource sector and its supporting enabling sector.

Keywords: natural resources; aquaculture; oil \& gas; Australia; Norway

JEL classifications: N50; Q2; N70; O13 


\section{Introduction: natural resources and economic development}

Development economists have long been interested in the role of natural resources in economic progress (Prebisch, 1950; Singer, 1950). The academic discourse has particularly focussed on the idea of the 'paradox of plenty', or the 'resource curse', namely that development based on natural resources ultimately leads to a lower growth trajectory. Specialisation in natural resource production and export may divert investment and factors of production away from other sectors and cause the exchange rate to appreciate. After the boom, capabilities in other sectors have been permanently lost, leaving fewer options for growth (Auty, 2001; Corden \& Neary, 1982; Gylfason, 2001; Sachs \& Warner, 1995). Others have alternatively argued that the broader institutional environment, rather than the choice of product, matters for an economy's successful development (Mehlum, Moene, \& Torvik, 2006; De Ferranti, Perry, Lederman, \& Maloney, 2002). Economic historians have provided a different interpretation of this empirical question. Exploitation of abundant natural resources, they argue, was the prerequisite of modern economic development, dominating a transitionary stage before industrialisation. ${ }^{1}$ Sparse or unsuitable natural resources often explained belated industrial development (Pollard, 1982; Wrigley, 1988; Landes, 2003; Clark \& Jacks, 2007).

In a series of important contributions over the last decade, Ed Barbier has provided a bridge between the two sets of literature, economic and historical, arguing that natural resources are an important factor but not all resource abundant nations have become successful

\footnotetext{
${ }^{1}$ We use the term 'economic development' in this paper in the sense of the stages of economic change rather than merely the growth that generally accompanies it. Industrialisation is thus taken to refer to manufacturing industries as the basis of modern economic development in contrast to resource-based economic development which draws substantially on the natural resource industries.
} 
industrialisers. His 'frontier expansion hypothesis' locates a golden age of development in 1870-1914, when the USA, and to a lesser extent other economies, invested the rents from resource production on geographical frontiers into industrial diversification. By the 1950 s, he argues, the causal link between resources and development had been broken.

We argue against Barbier by showing that Australia and Norway have continued to specialize along a path of resource-based development rather than diversify into manufacturing, while being strong economic performers. We investigate two resource-based industries, aquaculture and offshore oil and gas, whose expansion in Australia and Norway since the 1950s has relied on innovation and knowledge transfers. While the precise timing and pattern of each industry's development varied between the two nations, we show that continued development in Natural Resource Industries (NRIs) followed a common framework and pathway. We do not seek to prove a direct causal link between NRIs and the economic performance of these two nations, but rather that investment continued to flow into these innovative sectors in the modern era.

\section{Barbier's frontier expansion hypothesis}

In his 'frontier expansion hypothesis', Barbier argues that some nations have exploited their resource abundance more effectively than others. Developing nations utilise resource opportunities on their physical 'frontier' - horizontally in agriculture and vertically in minerals - and trade these commodities: 'the earnings from such resource-based development ...[are] reinvested in productive economic investments, linkages and innovations that encourage industrialization and economic diversification' (Barbier, 2011, p. 20).

The 'Golden Age' of this mechanism, he argues, was 1870-1914, and the prototypical case was the USA. A large domestic market for resources, efficient internal transport networks, 
and relative protection from overseas competition, facilitated American economic development. The industrial transition occurred as manufactured goods, derived from the resource industries, were exported in large quantities - particularly iron and steel goods, copper manufactures, and refined mineral oil (Barbier, 2011, p. 397). The other 'Great Frontier' countries - Argentina, Australia, Chile, New Zealand, Paraguay, South Africa, Canada, and Uruguay - he argues, were less successful in diversifying away from resources. The later development of political institutions and smaller populations were limiting factors for the 'Southern Cone' nations, although Canada benefitted from easy access to American and European markets. The transition for the US was complete by the 1930s industrialisation had become self-sustaining and the "true "closing" of the western land frontier [had] occurred' (Barbier, 2011, p. 492).

For those nations seeking to transition from resource-based development to manufacturing after 1950, the link was broken and they faced an uncertain future locked into a resource 'enclave' form of development. Barbier identifies three key differences in the post-1950 period compared with earlier eras: frontier expansion was often on unproductive tropical and marginal land; globalisation made commodity exports easily accessible to other nations thus diminishing their value as an economic rent; and policy and institutional failures inhibited resource-based development.

Barbier's work is a valuable, original and integrating contribution, but has shortcomings. It assumes that resources sector specialisation, at best, is an intermediate step towards economic modernisation, which is characterised by manufacturing's rise to pre-eminence. Further development concentrated on NRIs rather than diversification, he argues, would create an economically isolated 'enclave'. His conception of NRIs and their growth-inducing potential focuses on agriculture and mining and, equally, that they require a physical frontier of natural 
resource abundance in order to flourish. ${ }^{2}$ We believe that growth-inducing diversification can equally occur within the broad resources sector and at different stages of a nation's development that may not include such a frontier. Recent economic historiography describes alternative pathways of economic development and, indeed, draws varying pictures of what a developed economy might look like (Austin \& Sugihara, 2013; Lloyd, Metzer \& Sutch, 2013).

The 'contemporary era' since about 1950 is summarised by Barbier as one of overall failure for resource-specialising nations, by conflating the development challenges of many nations in the so-called 'third world' with the overall performance of NRIs in this period. However, the stalled economic development of many nations in Latin America and Africa has had less to do with the quality of natural resources available to them on the frontier than with broader institutional questions, especially political stability and capabilities to use natural resources for economic development. Barbier correctly observes that a number of successful economies of this period, such as Japan and Hong Kong, had few domestic natural resources but were able to draw upon imported commodities. This is not a new story. International commodity trades were booming at the time of American industrialisation, an era believed to be the first phase of globalisation (O'Rourke \& Williamson, 1999). British industrialisation from the eighteenth century, besides domestic coal, required imports of cotton and wheat from North America, timber from the Baltic, and wool from Australia and New Zealand.

Australia and Norway are examples of nations that have developed by continuing to specialise in the production, and especially export, of natural resources. Australia is viewed by Barbier as a failure since it initially specialised in resource industries, wool and gold,

\footnotetext{
${ }^{2}$ Barbier (2015, p. 68) suggests that development based on natural resources may expand 'fixed' resources, that linkages may create dynamics in other parts of economy, and that there may be knowledge spillovers from NRI. However, the analysis and conclusion of the paper do not draw on these insights. The focus remains avoiding a natural resource enclave, instead using resource rents to invest in industrial production.
} 
largely unconnected to other sectors, and failed to make a sustained transition into manufacturing. In drawing this conclusion, he relies on a disputed view that Australian development had lost its way by 1914 (Schedvin, 1990). In the first half of the twentieth century, Australia sought to diversify into manufacturing assisted by tariff and import quota protection but this proved to be an abject failure and reduced operational and allocative efficiency within the economy. Protection was eventually reduced and mostly abolished in the final decades of the twentieth century. In the interim, the NRIs continued to innovate, diversify and remain the principal source of exports. Norway, another resource-based economy (RBE), rose to the top of the OECD rankings in terms of GDP per capita in the second half of the twentieth century. Its production focus has been forestry, fisheries and energy. Norway fits uncomfortably into Barbier's framework and is not analysed by him.

The remainder of this paper will investigate the expansion and diversification of NRIs in Australia and Norway since the 1950s in light of the Barbier hypothesis. It will demonstrate that economies could expand and prosper through diversification within the resources sector. Rather than enduring the disabilities of an enclave, we show that this focus provided important connections to sources of innovation. Moreover, NRIs could continue to prosper in this period and without the need for a new physical frontier to exploit. We argue that it is innovation frontiers that matter.

\section{An alternative development model: natural resource based knowledge economy}

We present an alternative hypothesis to explain why many developing economies with large NRIs failed to modernize during the second half of the twentieth century and the beginning of the twenty-first. We argue that by the first half of the twentieth century NRIs had transformed into knowledge intensive production capable of dominating long term economic 
development. Our hypothesis is that economies with relevant and sufficient innovation capabilities and institutions (most often generated from earlier experience in NRIs) were best placed to follow a natural resource development path by the $1950 \mathrm{~s}$.

We start from the observation that some developed small and medium sized economies that had specialised in natural resources continued to grow and improve living standards, including Australia and Norway (Smith 2007). ${ }^{3}$ The question we raise is: how did these countries succeed in using natural resources as a basis for development when other countries with similar endowments failed? Building on historical analyses from the USA and other countries during the Golden Age - a period also called the Second Industrial Revolution - we argue that NRIs became knowledge intensive (Wright 1990; David and Wright 1997; Ville and Wicken 2013). Their industrial dynamics moved from simple harvesting to dependency on complex scientific, technological and industrial systems. New types of organisations were established for the systematic development of new knowledge (public and industrial laboratories, research universities), education (universities, engineering colleges), and the application of new technologies for production (mechanical engineering) (Mowery \& Rosenberg, 1989; Bruland and Mowery, 2004). What now mattered for NRIs was innovation, rather than geographic, frontiers.

Knowledge-based production systems made NRIs a potential focus for continued economic development during the contemporary period. This is a topic of evolving work in several related fields analysing contemporary RBEs as dynamic and innovative - policy institutions (de Ferranti et al 2002), industrial economics and innovation studies (Smith, 2007; Iizuka \& Katz, 2012; Laestadius \& Noor, 2010, Andersen, 2011; Marin \& Smith, 2011) and development studies (Morris, Kaplinski, \& Kaplan, 2013; Andersen et al., 2015). A

\footnotetext{
${ }^{3}$ Countries belonging to this group; Australia, Canada, Denmark, Finland, Iceland, New Zealand, Norway, Sweden, the Netherlands.
} 
characteristic of this literature is that resource-based development is the outcome of processes where knowledge and technological development are central factors (Andersen, 2011; Ville \& Wicken, 2015; Andersen et al., 2015; Thune, Engen and Wicken 2018). This moves the analysis of long-term industrial development and diversification in RBEs away from the accumulation of financial capital from natural resource industries and its investment in new industrial sectors (Barbier, 2011). Rather, the focus is on how knowledge and learning processes - innovation - in NRIs are used to increase growth within the industry as well as diversification into new NRIs.

At the same time, all RBEs did not follow the same development pattern during the twentieth century. Smith and Wicken (2016) argue that they have "quite specific and identifiable combinations of characteristics, extending well beyond resource intensity in some abstract sense". These are shaped by each country's history, geophysical environment, location, demography, economic and social structures, and political systems. One way of defining categories of RBEs is to specify different types of core processes shaping long term dynamics and structure linked to natural endowment and resources. Drawing on Smith and Wicken (2016) and Andersen et al (2015), we point to five channels through which high-growth RBEs may connect innovation to economic development. The first two channels relate to dynamics within existing resource sectors: (i) growth and productivity increase within a resource sector; (ii) expanding/ extending existing resources by identifying new deposits and more extensive production. The three other mechanisms relate to diversification: (iii) creating or developing new NRIs by transforming new parts of the natural environment into resources for economic production; (iv) creating upstream and downstream industries within the resources sector; and (v) developing new industrial production sectors by lateral migration of knowledge and technologies away from NRIs. 
Australia and Norway primarily followed the development channel (iii) characterised as diversification by the creation of new natural resource industries. In addition, they improved productivity and expanded production in existing resource industries (i, ii). These processes were both dependent on, and the result of, relevant innovation capabilities. In the empirical sections of the paper we examine this type of development process by analysing diversification into two new RBIs in Australia and Norway, modern aquaculture and offshore oil and gas production, during the period of 'closed frontiers'.

In order to prosecute this approach, we extend a model for diversification, which had explained the interdependency between NRIs and their enabling sectors in the successful expansion of RBEs (Ville and Wicken 2013). The 'enabling sector' consists of knowledge intensive firms (capital goods industry, engineering services, business services, project management and operational specialists) and education and R\&D institutions, which facilitate innovation in the NRIs. In our model, the enabling sector provides an indicator of innovation capability in the economy; and instruments which regulate the development of the enabling sector and the relationship between the NRI and the enabling sector are seen as the main institutions shaping the direction of industrial development. This helps to structure the empirical analysis and the discussion of each industry. We describe how innovation capabilities (enabling sector) are involved in or built during each phase of the industry life cycle; and how public policies influence the growth of the enabling sector and the shape of collaboration between the sectors. 
Our extension of the earlier framework provides a dynamic analysis of NRIs from a life-cycle perspective by explaining their evolution from establishment (phase 1), to growth and transformation (phase 2), and internationalisation (phase 3). ${ }^{4}$

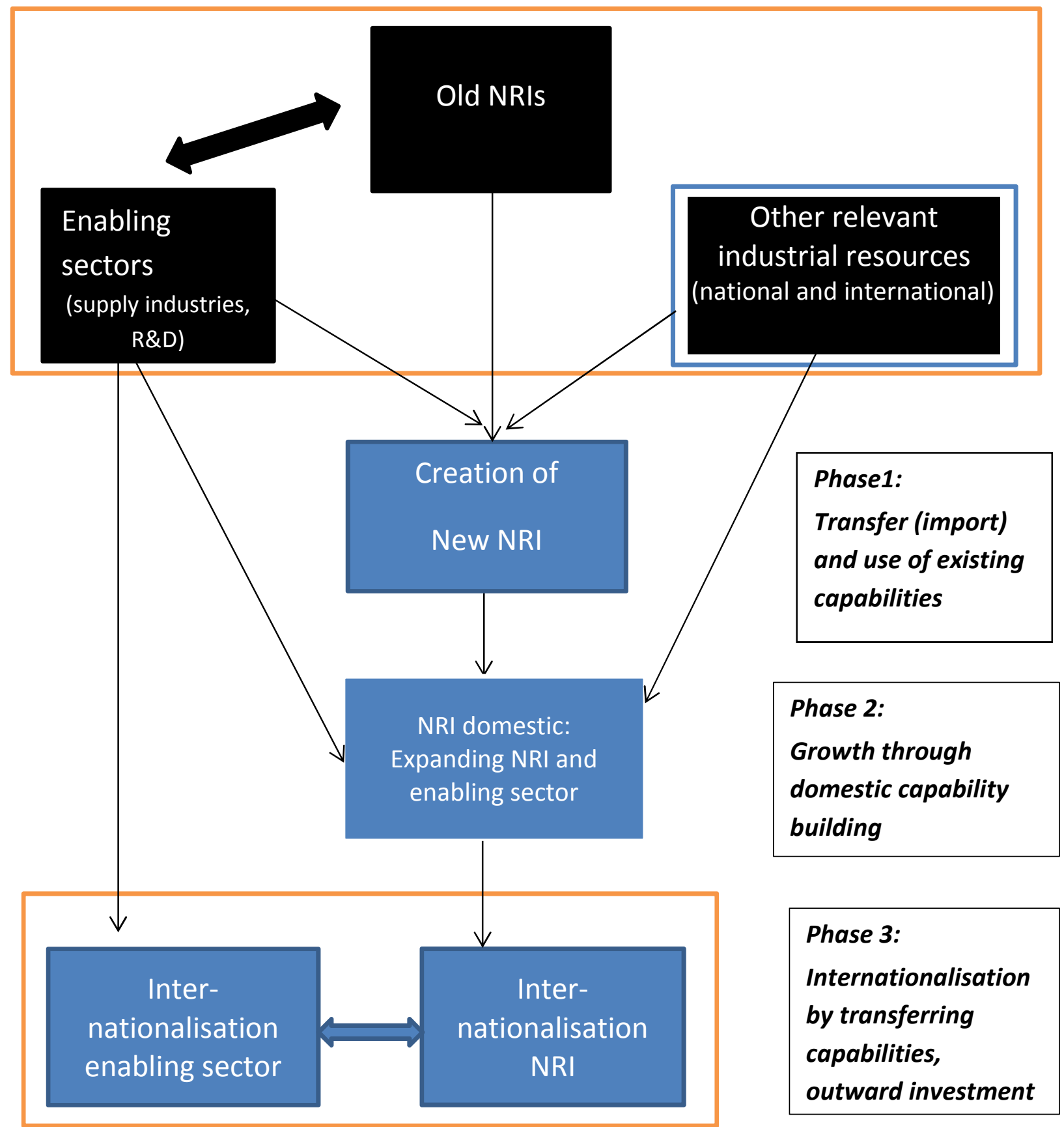

Figure 1: Model of dynamic evolution in natural resource industries

\footnotetext{
${ }^{4}$ In the long run, all industries can expect to experience stagnation and decline (phase 4), but we do not discuss this as it is so far not relevant for the cases analysed.
} 
Underlying the model is the proposition that development processes are path dependent (David, 1985). We assume that the development of new technologies and sectors are shaped by past historical experience. The creation of new sectors will, to some extent, build on capabilities derived from existing production, infrastructure, institutions and knowledge bases (Dosi, 1988). A central aspect of the path dependency concept is that as economies specialise, they develop knowledge bases, technologies, routines, and organisations relevant to these specialisations. Economies, in this way, become competitive within their specialisations - in the case of RBEs, specialisation in NRIs rather than manufacturing.

Empirically, we analyse how established organisations and competencies in Australia and Norway are utilised during the first phase of a new NRI; a phase involving transferring and using existing capabilities. In both countries the demand for new knowledge bases used in production increases as the new industry gradually expands and upgrades its capabilities. A wider set of knowledge intensive firms and organisations become involved in improved production systems, including many that are outsourcing key functions. This dynamic gradually increases innovation capabilities in the economy. In this second phase, we therefore focus on domestic capabilities building through problem solving activities linked to production and investment in new production units. Knowledge intensive organisations and firms (capital goods, engineering services, business services, project management and operational specialists, and education and R\&D institutions) will critically support problem solving and innovation processes in the NRIs. This dynamic may gradually spillover and increase innovation capabilities in the broader economy. A third phase of the model, internationalisation, occurs when natural resource firms and industries succeed in entering foreign markets by export and foreign direct investment (FDI). The new, domestically generated capabilities - knowledge and technologies - can be exploited across borders. Exports result from capabilities to increase domestic production, while FDI involves 
production in new markets, potentially both for firms in receiving and enabling sectors. Production in new territories created opportunities for continuous learning within new environmental and institutional contexts, improving efficiency and increasing the volume of production. In this way domestic NRI firms became global operators with production and sales in many markets.

\section{Australia and Norway: Creating natural resource specializations}

Australia and Norway belong to a relatively small group of RBEs whose long-term industrial development has followed a trajectory characterized by continuously creating, transforming, upgrading, and extending NRIs. While NRIs share of GDP in both countries has fluctuated over time, they have dominated the exports of both nations for much of their history, including in the last half century. As Figure 2 shows, in recent decades NRIs' share of merchandise exports for Australia has fluctuated within a band of 70-90 per cent and for Norway 60-80 per cent. While the causes of economic growth are manifold, both nations have been high performers as reflected in their similarly elevated positions in most international rankings, as shown in Table 1; for Australia and Norway respectively: of income (GDP/capita 12 and 3, 2016), welfare (UN Human Development Index, 2 and 1, 2009-16) and knowledge economy (World Bank index, 6 and 10, 2012). 


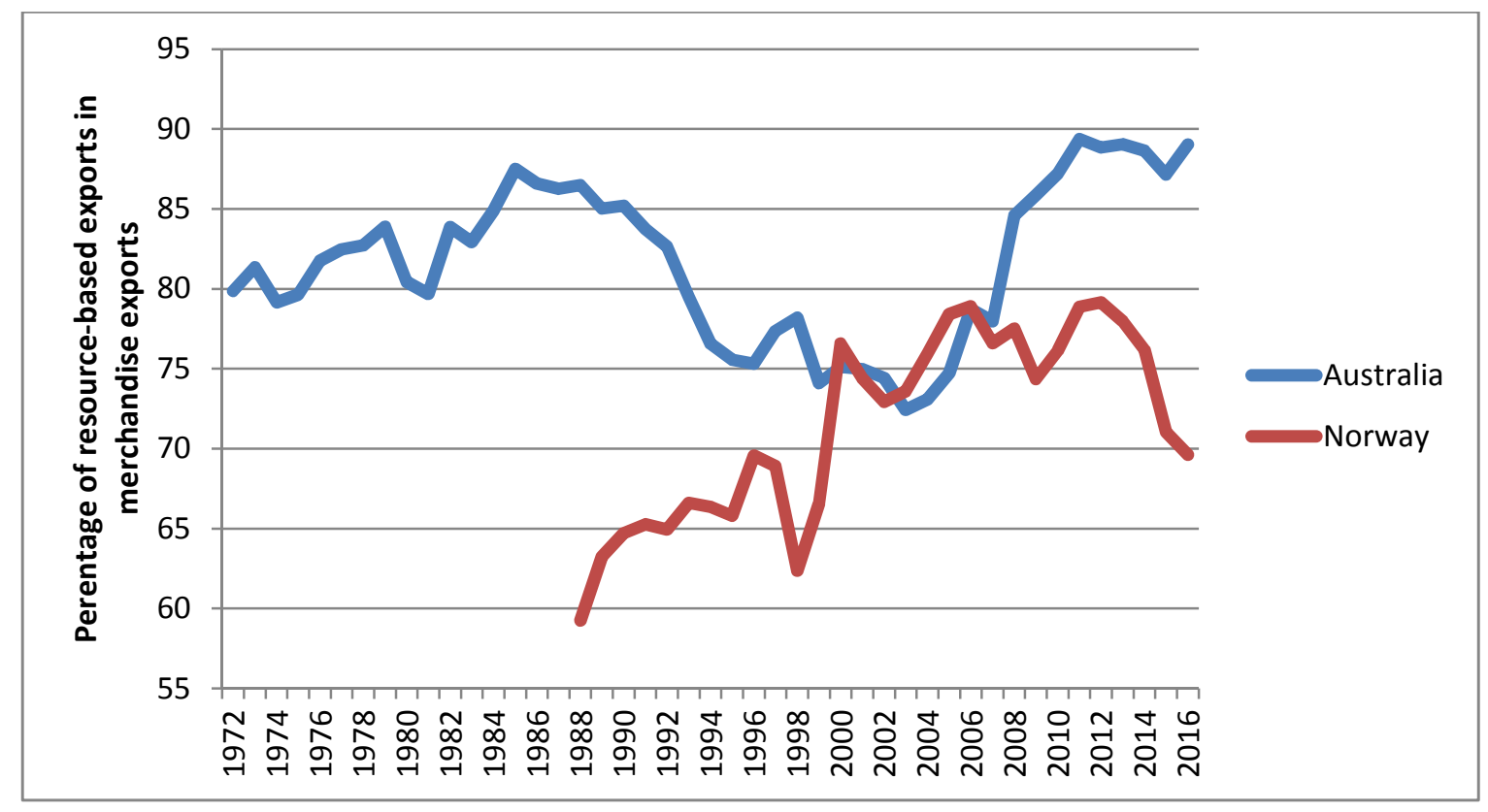

Figure 2. Resource-based exports, Australia (1972-2016) and Norway (1988-2016)

Sources and notes: For Australia, calculated from ABS Cat 5386.0, International Trade in Goods and Services including exports of meat, cereals, wool, other rural exports, metal ores and minerals, coal, petroleum and natural gas, metals and gold. For Norway, calculated from Statistics Norway 8819-1 including export income from hydrocarbons, fish, pulp and paper, nickel and aluminium.

Table 1: Performance Indicators for Australia and Norway

\begin{tabular}{|l|c|c|}
\hline Indicator & Australia & Norway \\
\hline GDP/capita (constant 2010 USD, PPP) (OECD 2018), rank & 12 & 3 \\
\hline $\begin{array}{l}\text { Welfare (UN Human Development Index, 2009-2016), } \\
\text { rank }\end{array}$ & 2 & 1 \\
\hline World Bank Knowledge Economy Index, 2012, rank & 6 & 10 \\
\hline
\end{tabular}

Sources: GDP/capita: OECD.Stats 2018. Welfare: UN Human Development Programme 2016. Knowledge Economy: World Bank KAPSARC data portal 2018

While broad similarities of sectoral orientation and overall performance are important starting points for a comparative study of innovation processes, there are also significant environmental and institutional differences that enrich the study and help to justify our choice of these two nations. The two countries are located geographically distant in opposite 
hemispheres, Australia has a much greater and warmer land mass and a larger population. Australia's colonial links with Britain have shaped much of its institutional frameworks. Norway's history has been closely tied to the neighbouring nations of the North Sea and Baltic although Britain has also been influential there. Educational and legal systems have also differed between the two nations. While both countries concentrated on NRIs, Norway has specialised in the production of a limited number of natural resource goods in fish, forestry, mining and later energy, while Australia, with its large geologically diverse landmass, diversified in production of a wide range of agriculture and mining commodities.

Ville and Wicken have analysed the evolution of Australia and Norway as RBEs in the nineteenth and early twentieth centuries elsewhere (Ville \& Wicken, 2013; Ville \& Wicken, 2015). In the remaining empirical sections of this paper, we analyse the dynamics of growth, transformation and diversification processes during the period from the $1950 \mathrm{~s}$ - the so-called contemporary era - where, according to Barbier, the link between specialisation in resource production and development has been severed. To do this, we provide case studies of two NRIs that grew to prominence in both countries in this period to which we evaluate the application and operation of our model of industry dynamics. While the two nations have historically focussed on different NRIs, the growth of first, offshore oil and gas, and second, aquaculture, in the latter half of the twentieth century was common to both. The post 1950 period is used as the overall frame to compare with Barbier's conclusions, while acknowledging that the size, timing and focus of that growth varied: Norwegian expansion in these industries occurred rapidly after 1980, while Australia's expansion was earlier but of lesser magnitude until the Liquified Natural Gas (LNG) boom a decade ago. We can also draw some distinctions between the two cases. While fishing has a long history, aquaculture only became significant in the latter half of the twentieth century. Oil and gas production has 
a much longer history in other nations - Australia and Norway were late starters. Aquaculture uses renewable resources, while oil and gas reserves are finite.

We deploy a range of data types and sources to investigate these two industries. The aquaculture industry's statistical parameters in terms of size, growth and product focus are taken from the Food and Agriculture Organization of the United Nations (FAO) for both nations. For oil and gas statistics, we use Statistics Norway, and for Australia APPEA industry statistics and production statistics from the Commonwealth Department of Industry, Innovation and Science. The more detailed case study evidence, quantitative and qualitative, comes from a range of sources for both nations. These particularly include historical studies of NRI companies and industries, government departments, research organisations, industry bodies, individual companies, and the secondary literature.

\section{Aquaculture: a new growth industry sector}

Aquaculture became a major industry in the second half of the twentieth century, although farming in water, as it is defined, has a long history. However, the new science of genetics, fish health knowledge, new types of fodder, production technology with large scale commercial breeding and farming of fish, often in purpose-built structures, created the bases for a new form of food production that distinguishes modern aquaculture. As Figure 3 indicates, after a slow start in Australia from the 1950s and a belated start in Norway from the 1980s, production in both nations increased sharply in the 1990s and continued to grow quickly through the quarter century to the present. Given the focus on the domestic market in Australia, however, its aquaculture production is much smaller than in Norway.

The structure of aquaculture production differs in the two countries. Norway has specialized in salmonid production, which constitutes more than 99 per cent of the industry with production units spread across the fjords of Western and Northern Norway (Statistics 
Norway, 2017). Australia has a more diverse industry, with pearls, oysters, Atlantic salmon, shrimp, and southern bluefin tuna farmed commercially, largely for domestic consumption. Currently the largest value of production is from Tasmania where the cool climate suits the production of Atlantic salmon, while South Australia accounts for most of the southern bluefin tuna. Between them, the two states generate 74 per cent of the $\$ 1$ bn aquaculture industry (ABARES, 2013-14, p. 13). Pearl farming is an important activity for remote parts of Western Australia and Northern Territory. In Australia, aquaculture accounts for around 40 percent of total fisheries output (ABARES, 2015, p. 10); in Norway - the world's second largest exporter of marine resources (FAO, 2013) - the industry comprises 60 per cent (Richardsen and Bull-Berg 2016: 14).

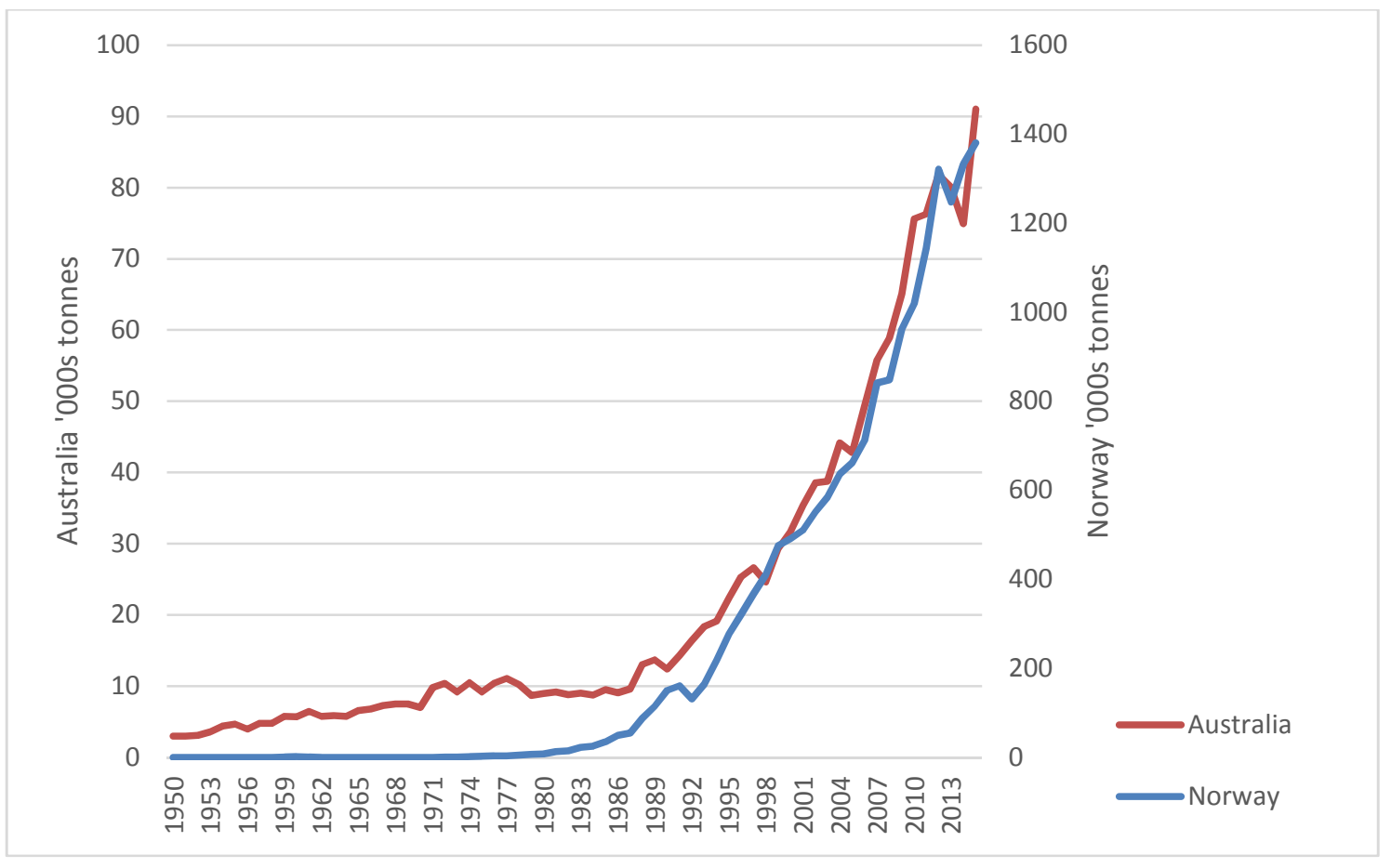

\section{Figure 3. Aquaculture production in Australia and Norway}

Source: Food and Agriculture Organization of the United Nations, http://www.fao.org/fishery/statistics/collections/en accessed 1 November 2017

\subsection{Phase 1. Transfer of knowledge and use of existing capabilities}


The establishment of modern aquaculture demonstrates how a new NRI emerged by drawing on existing domestic knowledge and resources. This includes earlier ad hoc experimentation with fish farming, expertise in fisheries and agriculture, and existing mechanical engineering and service sectors relevant for the emerging industry.

Both nations had a long history experimenting with fish farming. In Australia, Sydney rock oysters were being cultivated from the 1870s (Schrobback, Pascoe, and Coglan, 2014, p. 155), while in Norway scientists experimented with fish breeding and production from the early twentieth century on the coast of Sørlandet (Schwach, 2000). However, more important for the start-up of aquaculture were existing resources, knowledge and competences in old NRIs, particularly marine industries, fisheries and agriculture. The traditional wild fishing sector was an important source of practical information together with tacit knowledge acquired from fishermen about local climates, maritime conditions, fish species, and the use of cages and traps (Berge 2006).

Acquisition of knowledge about optimal conditions has enabled breeding far from their natural habitats. As an exotic species to Australia, knowledge about Atlantic Salmon has had to be transferred from offshore, as well as developed locally. For example, salmon ova were imported into Australia from Nova Scotia in the 1960s and a hatchery was established in the Snowy Mountains. In the 1980s eggs from this hatchery were provided as the basis for the Tasmanian industry, and knowledge was transferred through a joint venture with Norwegian investors (Harrison 2006). Pearl farming also relied on both locally developed knowledge and knowledge transfers from Japan. While Australian barramundi is a tropical fish, knowledge about its natural environment has enabled this species to be farmed in temperature-controlled tanks in the cooler southern states. In South Australia, many Southern Bluefin Tuna fishermen moved into the new tuna ranching industry as wild stocks were 
depleted. This was assisted by research by state-sponsored organisations and knowledge was shared via the formation of local and state aquaculture associations.

In Norway the early phase of salmon production was largely based on experimentation by fishermen and farmers, who drew on their experiential knowledge from ocean and coastal fisheries. Some early fish farmers had experience in the use of closed net cages near to shore to keep saithe alive. Fishers' experience and knowledge of the local environment was crucial for decisions about locations for aquaculture production and for mooring nets securely to the sea floor. Moreover, technologies used in fisheries were introduced into aquaculture, exemplified by the use of pumps on fishing vessels for removing fish from net cages (Berge, 2006, pp. 411-12). An important element of the emerging salmon industry was genetics research. A programme using genetics to increase the survival and growth of Atlantic salmon began in the 1960s at the Norwegian University College for Agriculture, and early research built on the College's experience of genetic selection of breeding livestock. As the industry evolved, it continued to draw on various knowledge sources in agriculture such as animal health, fodder, and distribution.

During this early phase, regulations were introduced to control salmon production. From the 1970s a decentralized industrial structure with small-scale production units was promoted. A license system restricted individuals to ownership of one production unit. Before 1990 more than 800 licenses were issued, mainly to fishers and farmers, supported with a subsidy scheme. The policy provided the basis for collaboration between producers and the many small-scale workshops that had experience in providing equipment and solutions for coastal and ocean fisheries as well as for shipping. In some regions of Norway, new ideas, practices and technologies diffused rapidly due to open relationships among fish farmers, aquaculture consultants, fodder producers, and technology suppliers (Berge, 2006). 
An indication of the diverse industrial background of salmon production was the discourse on whether the emerging industry should be defined as part of agriculture or fisheries.

Entrepreneurs came from both industries as did technologies, skills, and scientific knowledge. The new industry was initially under the umbrella of agriculture, and only after a long period of discussion became part of fisheries (Berge 2006). In a similar vein, in Australia many of the investors in the early Tasmanian aquaculture industry were horticulturalists seeking to diversify away from apple growing (Harrison 2006).

\subsection{Phase 2. Growth and transformation: building domestic capabilities}

Over time production systems became more technologically advanced, improving productivity and benefitting from economies of scale. Studies of aquaculture in the mid 1990s illustrate the complexity and diversity of knowledge bases that evolved to support the development of the industry. These included scientific specialities such as wave analysis, optics, robotics, spectography, chromography, electron microscopy, and various fields of technology including materials technology, surface technology, construction and welding, information technology, gas technology, electron microscopy, control technologies, extrusion technology, monitoring, high pressured air and liquid technologies, refrigeration, bio technology, and nutrition technology (Dietrich, 1995). Modern aquaculture became a hightech and science based industry. Many of the research and knowledge needs were common to all firms, which tended to be small and fragmented. The governments in both countries supported the expansion of research institutions investigating aquaculture, and the development of a public knowledge infrastructure. The expertise and reach of existing government bodies was brought to bear on the challenges of the industry.

In Australia, the Commonwealth Scientific and Industrial Research Organisation (CSIRO) and its predecessors, has undertaken research for NRIs since 1916. In recent decades its work 
for aquaculture has included breeding, feeds, and disease control. ${ }^{5}$ In addition, the Fisheries Research and Development Corporation (FRDC) was formed in 1991 under the Commonwealth Department of Agriculture to identify priorities for industry research and to direct funding, drawing representation from industry, industry groups and government. The goal was to create "a national system in which end users of the research take a leading role in determining and reviewing strategic directions and priorities" (FRDC, 2010, p. 8). An early landmark activity was collaborative $R \& D$ on ranching southern Bluefin tuna drawing in the Tuna Boat Owners Association, the South Australian Government, and the Japanese government. The Commonwealth's 2002 Aquaculture Action Agenda was designed to encourage industry and government to work more closely together in an effort to enhance sustainable competitive advantages (AFFA 2002). More recently, the 2017 National Aquaculture Strategy aims to double the value of Australia's aquaculture output in the decade to 2027. (Department of Agriculture and Water Resources 2017).

In Norway, the first dedicated research centre for aquaculture, Akvaforsk, was founded by the Research Council for Agriculture in 1971. The gradual development of an industrial value chain with specialized producers and suppliers for each stage of production was reflected in the variety of R\&D programmes. Aslesen (2004) mentions 13 different programmes. By 2008 there were 20 public or semi-public research institutes with 1600 researchers located in various parts of Norway undertaking aquaculture research (Aslesen, 2009, p. 215). The national research programmes were directed towards increasing production and productivity in the industry. This involved improvements in fish breeding and fodder to increase the rate of growth, resulting in the introduction of dry-feed and the ability to feed fish in their larval stage (Schwach, 2000, p. 23). Another important aspect was the development of vaccines

\footnotetext{
${ }^{5}$ https://www.csiro.au/en/Research/AF/Areas/Aquaculture
} 
against parasites, bacterial and viral infections, which both drastically reduced the volume of antibiotics used and permitted more fish in each production unit (Aslesen et al, 2002).

In both countries, a wide range of training has been offered by universities and research institutes. In Australia, Cooperative Research Centres involving universities, CSIRO, and state government primary industries departments, existed between 1993 and 2008, and the Seafood Industry Training Package (SITP) was introduced in 2002 to provide a standard Vocational Education and Training (VET) curriculum across Australia. The Institute for Marine and Antarctic Studies (IMAS), formed at the University of Tasmania in 2010, has provided a range of tertiary-level training in aquaculture as well as conducting collaborative research. In Norway, specialised education in aquaculture was introduced at secondary level from 1994, and four universities have developed higher education programmes.

In Norway, an important policy change in 1991 allowed permits for aquaculture production to be traded, with the result that ownership consolidated around a few large investors. This changed the industry's dynamics, creating a stronger and more sophisticated demand for technologies and services to improve efficiency, reduce costs across the production chain, and solve fish health problems. As a result there was a growing market for firms that could provide advanced inputs, capital goods, and services. Many firms in the enabling sector specialized in providing services and equipment for aquaculture. The supply industry also consolidated into a group of well-resourced firms enabling the industry to innovate: production of fodder (Ewos, Skretting, Biomar), machinery and transport equipment (Seaside, Melby Systems, Optimar, AKVA, Aqualine, OCEA, Rolls Royce Marine); fish health (Europharma, Fiskehelsetjenesten, Scanvacc), and various consultancies and finance institutions. 
There is less evidence of the emergence of a specialised capital goods sector in Australia, reflecting its smaller size, geographic dispersal and lack of species specialization. However Australian companies such as Ridley have begun production of specialised feeds for a range of different species.

\subsection{Phase 3. Internationalisation of capabilities and production}

Norwegian aquaculture has become the world's leading producer and exporter of salmon, mainly to the EU, and to a lesser extent to the USA and Asia (Statistics Norway, 2017b). However, as the industry consolidated during the 1990s, investors also began to systematically invest in facilities in other countries. This form of internationalization may be seen as a combination of a high capability for innovation and production in the industry combined with limited opportunities for domestic expansion due to production regulations (Aslesen, 2009, p. 225). Investors turned to countries with less regulation, including Scotland, Canada, and Chile (Berge, 2002). By 2007 over 1/3 of Chilean aquaculture was owned by more than 60 Norwegian firms. Subsidiaries of multinational corporations played a central role including Marine Harvest in fish farming, CERMAQ in fish farming and fodder, AKVA Group and Ocea as suppliers of equipment, Pharmaq in pharmaceuticals. A number of small and medium sized service companies were also active (Astroza, 2008). In this way, the internationalization process involved firms belonging in both the recipient and enabling sectors. Parts of the supply industry such as fish fodder producers and R\&D organisations followed producers to new markets. Fodder producers, in particular, became active in all major salmon producing markets (Aslesen, 2009, pp. 212-13). By 2010, four of the leading six global seafood companies were Norwegian (OECD, 2010, pp. 151-2).

By contrast, internationalization of the Australian industry has focused largely on exporting production, concentrating on salmonids, as well as pearl oysters, southern Bluefin tuna, 
pacific oysters, shrimp, abalone, barramundi and yellowtail kingfish. (Department of Agriculture and Water Resources 2017). 46 per cent of Australia's aquaculture output by value was exported to Asia in 2013-14 (ABARES, 2013-14, p. 1); the remainder serves growing domestic demand in the face of falling volumes from wild fisheries, and the sale of new varieties of fish locally. Australia's vast landmass and coast line have provided opportunities for domestic expansion.

Despite these contrasting practices, both nations were moving within frontiers that enabled them to exploit, through the global sale of high value products, their capabilities in creating and expanding a new industry.

\section{Oil and gas: Transfer and creation of an indigenous industry}

Australia's on-shore oil and gas (OG) exploration began early in the twentieth century, but it was the discoveries in the mid-1960s (Dongara in 1964, Barrow Island in 1965, Bass Strait in 1967) that started the modern growth trajectory of the industry indicated in Figure 4. On the Norwegian shelf of the North Sea, exploration commenced in 1966, the first commercial discovery was in 1969 (Ekofisk), and production began in 1971. Many new discoveries followed and by the early twenty-first century it was gas that dominated output in both countries. Both countries have become important in international gas markets - Norway in natural gas, where it is the second largest provider to the EU. Meanwhile Australia is on track to become the world's largest exporter of LNG. 


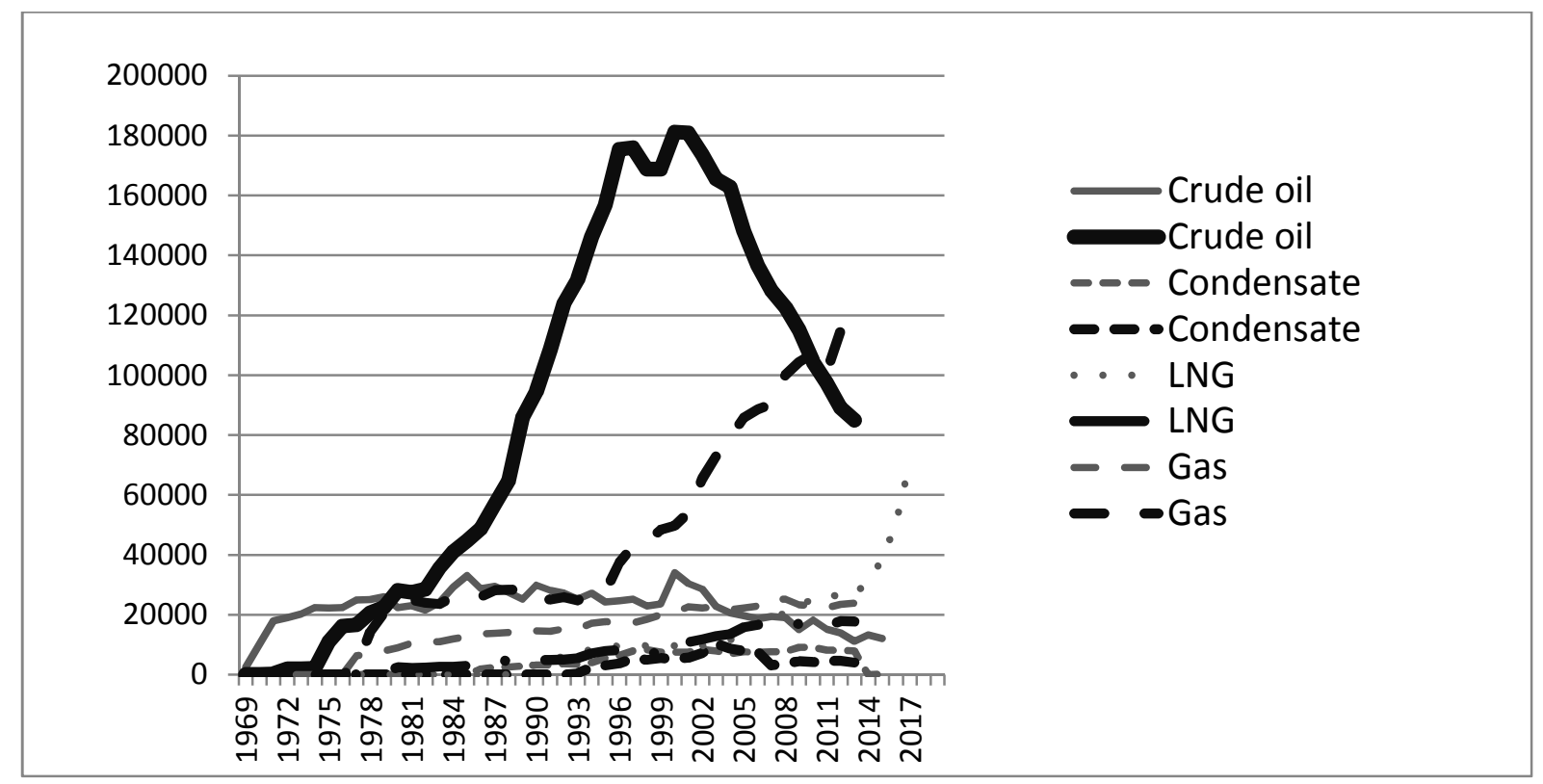

Figure 4. Oil and gas production, in Australia (1969-2015) and Norway (1970-2015)

From the first commercial discoveries, it was evident that Norway would become a significant exporter of oil and gas (Stortinget, 1974, p. 5-6) and by 2003-4 Norway was the third largest exporter of oil and gas globally (Regjeringen, 2005). At the peak (2008) of the petroleum era, OG production represented 25 per cent of GDP, 53 per cent of total export value, accounted for 35 per cent of total state revenues, and 21 per cent of total investment (Norskpetroleum.no, 2017). Norway became a petroleum economy.

In Australia, OG was initially less significant, being one of many NRIs. Early discoveries were relatively limited and were important for energy security, but had less economic impact. However, the picture changed as exploration moved offshore. Major fields were discovered on Australia's North West Shelf (NWS) at the same time as the emergence of technology to liquefy gas, critical for its transport where pipelines did not exist. Early projects came on line during the 1980s, building up to a rapid increase in production and export from the 2010s. This pattern will continue as the Prelude, Wheatstone and 
Ichthys projects come on line in the period to 2019. Together with the existing projects, export income from LNG projects is expected to reach AUD37b in 2018-19, which will make LNG Australia's third largest export earner behind iron ore and coal (Cassidy and Kosev, 2015, p. 35).

\subsection{Phase 1. Transfer of knowledge and use of existing capabilities}

The establishment of the oil and gas industry in Australia and Norway differed from the pattern for aquaculture. OG was already a mature global industry when exploration and development took place in these countries from the 1960s. The Gulf of Mexico was the leading offshore oil and gas producing region, and US companies brought to Norway and Australia their suppliers, organisations, technology, expertise, routines and regulations. Australian and Norwegian companies, as recipients of this know-how, were able to absorb these capabilities, modify them, and develop successful local industries through new relationships with the global players and their networks.

Expansion involved local firms that already operated in global production networks. In Australia, BHP had been Australia's largest firm for much of the twentieth century. It owned and operated mines, smelters and steel mills, and possessed significant engineering and manufacturing capabilities, including shipbuilding (Fleming, Merrett, \& Ville, 2004, p. 104). To develop its capabilities in OG, in 1960 BHP engaged former Esso geologist, Lewis Weeks, and on his advice procured exploration rights over much of Bass Strait, the sea between mainland Australia and the island of Tasmania. Esso became BHP's partner and provided the know-how for offshore exploration and, after discoveries were made, the joint venture contracted Esso's suppliers. Engineering, Procurement and Construction 
Management (EPCM) firms such as Fluor were engaged to manage platform and other infrastructure construction. According to Fluor :

'the specialised know-how came from Fluor's Houston office, but once front-end engineering was completed, ... the detailed engineering and procurement were conducted locally. (Fluor 2018)

A similar pattern was evident on Australia's west coast where petrol retailer AMPOL established a consortium with US oil major Caltex (West Australian Petroleum - WAPET) in 1952, which was later joined by Shell. WAPET discovered the Dongara gas field in 1964, and then oil at Barrow Island, which began production in 1967. Similarly, in the early 1960s, Woodside partnered with Shell and Burmah Oil as a consortium for exploration and development of the North West Shelf.

In Norway local firms did not play a significant role in the development of the oil sector until the discovery of large oil fields. Norway's largest manufacturing company, Norsk Hydro, with international experience in chemical and metal processing, had entered into a joint venture with the French OG major Petronord in 1965. This secured a small (6.7 per cent) Norwegian ownership in the Ekofisk field, and Hydro was the only local company involved in early-stage development of the field (Johannessen, Rønning and Sandvik 2005: 278). Local industries then became engaged in the emerging industry as suppliers of services and technology. Norwegian shipowners had been involved in oil transport since the 1920s - by 1965, 20 per cent of the global fleet of oil tankers was registered in Norway (Ryggvik, 2013). The international oil companies encouraged shipowners to enter the North Sea rig market. The international economic crises of 1973-4 created a huge downturn in the demand for ship building so many firms turned to the expanding oil industry. By the mid-1970s Norwegian shipping firms dominated the rig market, having assembled a fleet of 25 semi-submersible 
drilling rigs. The local industry's success has been linked to its domestic experience in managing the risks of speculative orders, which enabled it to have rigs available when demand increased during the 1970s (Ryggvik, 2013). Through its supply relationship with shipowners, Norway's largest ship building company, Aker, moved into the OG sector. It designed the Aker H-3 semi-submersible drilling rigs, which in 1973 were procured by shipowners. Aker itself was owned by the shipowner Fred Olsen, who had been involved in oil transport for decades and had attempted to enter the North Sea OG industry during the 1960s (Hanisch \& Nerheim, 1992).

\subsection{Phase 2. Growth and transformation: Building domestic capabilities}

The offshore OG industry comprises a value chain of exploration, field development, construction of production facilities, drilling, production, transportation, refinement and distribution. Each part of the chain requires several different capabilities that involve a large variety of technologies and knowledge bases. In both Australia and Norway, the demand from the OG sector has resulted in the development of a diverse supply and services industry, including a significant $R \& D$ sector.

\section{Building R\&D institutions:}

In Australia, funding for OG R\&D came mainly from the public sector, with a focus on 'precompetitive' research to identify prospective areas for exploration. In 1946 the Bureau of Mineral Resources, Geology and Geophysics was established to provide a comprehensive survey of Australia's geology (Johns, 1976). By the early 1960s its ambit was extending offshore with the aim of providing information about prospective regions for exploration, without undertaking exploration directly. The Bureau was responsible for the introduction of 
new survey technologies to Australia, including introducing Vibroseis technology in 1964, which eliminated the need for explosives to create a seismic source in surveys.

In Norway, the demands of the large OG industry had a more profound impact on the overall national R\&D sector. The public sector has both funded R\&D directly, and established new policy instruments encouraging international oil companies to invest in R\&D in Norway. From the 1980s the government's Technology Agreements required that, in order to obtain a development licence, international companies had to undertake at least half of their total research and training linked to operations on the Norwegian Shelf in Norway. This had a strong impact on the size and organization of the national research system (Gulbrandsen \& Nerdrum, 2009). In 1979 petroleum related research funding was NOK200m; in 1986 it had increased to $1,600 \mathrm{~m}$. Of this, only seven per cent was state funding, and more than NOK500m originated from oil companies. Two years later, the total OG R\&D funding reached NOK2,000m and only NOK200m was from the state (Ryggvik, 2000, p. 116). These arrangements catalysed interaction and collaboration between many Norwegian firms and international oil companies. The intention was to promote learning and technology transfer to local industry, and to engage local firms with the OG international production chain. The emerging research system was focused on the problems of users of industrial research. Local firms and international companies became engaged in common processes, and integrated their activities with international industrial learning communities.

However, the accession of both countries to the World Trade Organisation in 1995 introduced obligations to treat all suppliers equally, irrespective of country of origin. This was the end of polices for national control or privileges for local industry. In line with these obligations, the Norwegian government's strategy shifted to increase public R\&D. A broad portfolio of innovation and R\&D programs was introduced. The main form of support was tax policy, along with a rapid increase in public funding of $\mathrm{R} \& \mathrm{D}$. Currently there are 21 different forms 
of support systems for the OG sector. The funding from the Research Council of Norway (NRC) increased from NOK300m in 2005 to NOK1,300m in 2016 (Norwegian Research Council, 2017, p. 198).

The discovery and initial investment in large gas fields in the 1990s encouraged the extension of public research in Australia. Cooperative Research Centres (CRCs) connected with the oil and gas sector have been supported by the Commonwealth Government and its key research agency, the Commonwealth Scientific and Industrial Research Organisation (CSIRO). These include the Australian Petroleum CRC (1991-2003), the Australian Geodynamics CRC (1993-2000), the Energy Pipelines CRC (2010-2020), the CRC for Integrated Engineering Asset Management (2003-2013) and the CRC for Contamination Assessment and Remediation of the Environment (2011-2020). The University of Western Australia established a Centre for Offshore Foundations Research and CSIRO developed interests in petroleum research. For example, the Subsea Pipelines Collaboration Cluster, formed in 2008 across six universities and the CSIRO, has contributed technology to the development of the Gorgon gas province. Some private R\&D is also linked to OG sector. For example, CISCO established an innovation centre at Curtin University with Woodside Petroleum as a foundation partner. Woodside receives a holistic view of the platform's operations, and gains productivity benefits.

\section{Supply industries of the enabling sector:}

Both countries developed an enabling sector to support the development of OG. The build-up of Australia's enabling sector had been assisted by the changing relationship between global oil companies and local supply firms. BHP's partner Esso was the developer and operator of the Bass Strait fields, as we saw earlier. The platforms for Bass Strait were initially fabricated at the supply base established by Esso in Gippsland, drawing on Esso's experience in the 
Gulf of Mexico. Over time, BHP emerged as an operator in the OG sector in its own right, building on its experience, and through acquisitions and recruitment of expertise. Similarly, Woodside, initially partnered with Burmah Oil and Shell, then emerged as an explorer and operator in its own right. These local majors in turn developed close relations with the emerging enabling sector in Australia.

Fabrication of platforms and gas trains was initially undertaken close to their locale. However, modularisation and innovation has made it feasible to import infrastructure of this type. It was reported that there was $70 \%$ local content for the first three phases of Australia's first major LNG project, however this has decreased in subsequent projects - perhaps to 30 per cent in places (Parliament of Australia, 1998, p. xiv). In line with WTO obligations, the focus of government policy has been on 'Australian Industry Participation' (AIP). The objective has been to ensure Australian suppliers received 'free and fair' access to opportunities to bid. The cornerstone of AIP has been to bring the capabilities of Australian suppliers to the attention of purchasers further up the supply chain, on the basis that international EPCM firms lacked knowledge about local supply capabilities and conditions. The development of Floating LNG (FLNG) technology for the Prelude involves a massive floating facility that eliminates the need to bring gas onshore, being loaded directly to carriers. This raises questions about the economic benefits that will accrue to Australia from this type of production.

In Norway, local oil firms became operators from the 1980s. Statoil, a state-owned oil company established in 1972, became the dominant player, but Norsk Hydro was also an important firm. Both developed skills and expertise through collaboration and systematic training of personnel with the international majors. Statoil exemplifies the important role of oil companies in developing the service and supply industry. It became a policy instrument providing contracts to local industry in the development of new fields and operations, 
deliberately strengthening interaction between supply firms and oil companies. The 1973 recession added impetus to this approach, as the crisis in the shipbuilding sector, caused a shift to exploiting the high local content opportunities in the OG sector. Accordingly, local content increased from 18-25 per cent prior to 1975, to 50-60 per cent after 1977 (Ryggvik, 2013, pp. 44-6).

The concrete Condeep platform typified the results of the local content policy. In the 1970s Norwegian firms could draw on expertise from the construction of dams for hydropower to design and produce huge platforms which became the core of the 'Norwegian technological style' (Sejersted \& Olsen, 1997). To a large extent, the local content was characterised as 'cement bashing'; with large quantities of material requiring little advanced knowledge. Instrumentation of the platforms continued to be imported, and mainly provided by American companies (Ryggvik, 2000). By the late 1980s this technological style was no longer profitable, and the government initiated policies to reduce costs and to develop new technological concepts and processes. ${ }^{6}$ A core idea of the NORSOK process was the development of standards for a modular production process, allowing different companies to produce various components. This mobilization of existing capabilities became the basis for a dynamic innovation system where the industrial actors - oil companies and main suppliers enjoyed greater freedom in choosing technological solutions, partners, and the geographical location for production (Engen, 2009, p. 201). A new technological trajectory emerged, characterized by greater use of unmanned installations and computer based technological solutions linked to subsea technologies and new drilling techniques.

\subsection{Phase 3. Internationalisation of capabilities in subsea and LNG}

\footnotetext{
${ }^{6}$ NORSOK was introduced in 1994 to set industry standards regulating such matters as safety and costeffective design.
} 
During the 2000s, the OG industry in both Australia and Norway globalised, through large investments in many producing regions. Statoil (merged with Norsk Hydro in 2007) invested widely in new offshore oil fields in Asia (Azerbaijan), Africa (Algeria, Angola, Libya, Nigeria), Australia, and the Americas (Brazil, Venezuela, USA) (Ryggvik 2013). The company has also developed capabilities in unconventional resources such as oil sand in Canada and shale in USA. BHP's overseas expansion from Australia has taken it to onshore and offshore locations in the US, Algeria, Trinidad and Tobago, Pakistan, and in the North Sea. By 2015, BHP's Australian assets were only one sixth of its global petroleum asset value (BHP Billiton, 2015, pp. 73-4). Woodside has projects in the US and Canada, and exploration rights in Peru, Gabon, Senegal, Morocco, Ireland, Myanmar, New Zealand and Korea (Woodside Petroleum, 2017). Oil Search is an LNG partner with ExxonMobil in Papua New Guinea, and has exploration sites in the Middle East and North Africa.

Both countries have developed an enabling sector with relevance in global markets. By the early 2000s, Norwegian firms supplied technology and services to major international oil companies and main contractors; covering most of the upstream production chain from exploration and drilling to production and operation (Ryggvik, 2013). The offshore enabling sector became Norway's largest manufacturing industry, and also a significant producer of knowledge intensive businesses (Wicken, 2016).

In 2016 the Australian Trade Commission identified around 95 enabling sector companies with capabilities relevant to global markets, often honed by working in the remote and hostile environments of Australia. Local companies, often small and medium enterprises, have developed advanced tieback (connection from a new field to an existing production facility), flow assurance and foundation modeling technologies and innovation around construction productivity, safety, computational geosciences and subsea production. Separately, based on a review of a database maintained by the Commonwealth Department of Industry, Innovation 
and Science, in 2017 there were about 400 Australian firms directly involved in supporting the offshore oil and gas sector, including around 150 that are exporters (Dean, 2017).

There are also several contrasts in the globalisation practices of the two countries. In Australia, internationalisation from the mid-1980s drew on experience developing large offshore gas reservoirs in local waters, as well as building infrastructure for the distribution of natural gas domestically. Growing capabilities fostered the offshore investments of Australian firms (BHP, Woodside and Oil Search). From the late 1980s, large discoveries and the development of new fields created potential for the export of gas. However, it was the development of gas liquification, along with specialised shipping, that was the critical precondition which enabled global expansion of the Australian OG industry through large scale exports.

In Norway, the number of new OG fields was more limited from the late 1980s and future expansion was linked to engagement in emerging oil regions (Ryggvik 2000). Government policy aimed to develop a wider industrial strategy by combining OG production with the development of a strong supply industry. A new organization, INTSOK (Norwegian Oil and Gas Partners), was established in 1997 to promote Norwegian standards globally. Norwegian firms became dominant in several sectors of the OG supply industry. By 2012 Norwegian companies had secured 50 per cent of global market for sub-sea technology; 80 per cent for drilling equipment, 50 per cent for seismic equipment (Rystad Energy 2017). This success was the result of long term experimentation with sub-sea technology in the North Sea, which became a 'global field laboratory' of innovation (Ryggvik, 2013, p. 106), and formed the basis for learning processes developing capabilities in sub-sea technology and operations. By the end of the long boom of the oil sector in 2014, the supply industry was Norway's second largest export sector, only trailing the OG industry itself (Mellbye, Fjose, \& Jakobsen, 2012). In addition, many companies had invested in production and service offices in major OG 
regions in Africa, Latin-America, and Asia. For the first time, Norway had for first time a large high-tech industry operating globally.

\section{Conclusion}

This paper extends an important developing literature on the role of natural resources in economic development. It builds on recent work that shows that resource-based economic growth is not merely a transition stage to modernisation, nor is persistence along this pathway feted to general economic failure. Barbier's work brought together both of these traditional views in an historically specific manner. He argued that resource led development reached its apogee, or golden era, in late nineteenth and early twentieth-century America but that this important pathway to growth was closed after 1950.

Building on earlier scholarship which demonstrated that Australia and Norway, both resource-based developers, were among the most successful nations in this golden era, we analyse their development after 1950. In this period both nations continued to be among the best global performers on most socio-economic indicators. We investigate two of their NRIs, aquaculture and the offshore oil and gas sector; one a relatively new NRI, the other with a much longer international history. In both countries, these industries expanded rapidly and progressed through three stages from importing knowledge from antecedent industries, the expansion of domestic output and capabilities, to internationalisation by export and foreign direct investment.

Within these common patterns there were, nonetheless, some differences in experience between the two nations. In particular, Norway's range of resource industries was much narrower than Australia's. Such specialisation brought both benefits and challenges. It fostered directed government policy support and provided Norway with the opportunity to establish global leadership in several products. On the other hand, Australia's diversity of 
resources enabled it to move flexibly in response to shifts in demand and changing technologies.

A range of forces help to explain their success and the progression through the three stages. The adaption of legacy knowledge from older industries, the interaction between recipient sector and enabling sector, and the growing strength of the latter all played key roles in building capabilities and competitiveness. While Barbier's main focus was on the investment of financial rents transferred from the resources sector, we explain the role of the generation of new knowledge through the interaction between sectors, and in this case within the NRIs. The broad sectoral linkages implicit in these interactions - including science, engineering, business services and even manufacturing - testify to the fact that economic development can occur through diversification and specialisation within the resources sector but without creating enclaves. Explicit measures of innovation across sectors are complex and fraught with methodological issues, and therefore are beyond the scope of this paper. However, there is evidence in the literature to confirm that modern resource industries could be more innovative and productive than their counterparts from other sectors, especially manufacturing, in Norway, Australia and other major resource-based economies (Simensen and Thune 2018; Scott-Kemis 2013; Marin and Petralia 2018).

The cases confirm our theoretical perspective that natural resources are not a fixed value in the environment, rather their extension relies heavily upon innovations that push back the technology frontier, not the physical frontier. Future research might investigate whether the experiences of these two countries and the two case industries can be generalised to other resource-centred nations and sectors for this relatively contemporary period that Barbier has found lacking in innovation. Certainly, Australia and Norway were part of a relatively small group of resource-based economies with a long history of successful development that benefited from stable institutions. We might expect to find similar experiences in New 
Zealand, Canada and Sweden for example. The choice of two industries was justified by their post-1950 expansion in the two economies. The set of innovations and enabling bodies discussed were largely specific to the oil/gas and aquaculture industries. However, similar generalised dynamic processes - drawing on older NRIs, foreign expertise and government policies, as per figure one - might reasonably be expected apply to other NRIs. We welcome further research on this topic. 


\section{References}

AFFA (Department of Agriculture, Fisheries and Forestry). (2002). Aquaculture Industry Action Agenda National Aquaculture Development Committee's Report to Government and Industry, Canberra

Andersen, A. D. (2011). Innovation Systems and Natural Resources - the case of sugarcane in Brazil (Unpublished doctoral dissertation). Aalborg University, Aalborg.

Andersen, A. D., Johnson, B., Marín, A., Kaplan, D., Stubrin, L., Lundvall, B.Å., \& Kaplinsky. R. (2015). Natural resources, Innovation and Development: Globelics Thematic Review. Aalborg: Aalborg University Press.

Aslesen, H. W., Mariussen, ^̊., Olafsen, T., Winther, U., \& Ørstavik, F. (2002). Innovasjonssystemet i norsk havbruksnaring [Innovation system of the Norwegian aquaculture industry] (Report No. 16). Oslo: STEP.

Aslesen, H. W. (2004). Knowledge intensive service activities and innovation in the Norwegian aquaculture industry (Report No. 5). Oslo: STEP.

Aslesen, H. W. (2009). The Innovation system of Norwegian aquacultured salmonids. In J. Fagerberg, B. Verspachen, \& D. Mowery (Eds.), Innovation, path dependency and policy: The Norwegian case (pp. 208-34). Oxford: Oxford University Press.

Astroza, A. (2008). Norwegian multinational firms in the Chilean salmon farming industry: Developing prerequisites for innovative activities in host countries (Unpublished master's thesis). University of Oslo, Oslo.

Austin, G., \& Sugihara, K. (Eds.). (2013). Labour-intensive industrialization in global history. London: Routledge. 
Australian Bureau of Agriculture and Resource Economics and Sciences (ABARES).

Australian fisheries and aquaculture statistics. Canberra: Department of Agriculture and

Water Resources. Various years

Austrade. (2012). Austrade Industry Capability Report - Oil and Gas. Canberra: Australian Trade Commission.

Austrade. (2016). Austrade Industry Capability Report - Oil and Gas. Canberra: Australian Trade Commission.

Auty, Richard M. (2001). The political economy of resource-driven growth. European economic review 45(4), 839-46.

Barbier, E. B. (2011). Scarcity and Frontiers: How Economies Have Developed Through Natural Resource Exploitation. Cambridge: Cambridge University Press.

Barbier, E. B. (2015). Scarcity, frontiers and the resource curse. In M. Badia-Mirò, V. Pinilla, \& H. Willebald (Eds.), Natural Resources and Economic Growth. Learning from history (pp. 54-76). London: Routledge.

Berge, Dag Magne. (2006). Havfiske inn i nye næringer [Ocean fisheries entering new industries], in O. Bjarnar, D. M. Berge and O. Melle (Eds.), Havfiskeflåten i Mфre og Romsdal og Trøndelag [Ocean fishing fleet in Mфre \& Romsdal and Trфndelag]. Trondheim: Tapir Akademisk Forlag.

Berge, D. M. (2002). Dansen rundt gullfisken: Naeringspolitikk og statlig regulering i norsk fiskeoppdrett 1970-1999 [Industrial policy and state regulation of Norwegian aquaculture 1979-1999] (Unpublished doctoral dissertation). University of Bergen, Bergen. 
BHP Billiton. (2015). Resourcing Global Growth: Annual Report 2015. Melbourne: BHP Billiton Limited.

Bruland, K. \& Mowery, D. (2004). Innovation Through Time. In J. Fagerberg, D. Mowery, \& R. Nelson (Eds.), The Oxford Handbook of Innovation (pp. 349-79). Oxford: Oxford University Press.

Cassidy, N. \& Kosev, M. (2015). Australia and the Global LNG Market. Sydney: Reserve Bank of Australia.

Clark, G. \& Jacks, D. (2007). Coal and the industrial revolution, 1700-1869. Review of European Economic History, 11, 39-72.

Corden, M. \& Neary, J. P. (1982). Booming Sector and De-Industrialisation in a Small Open Economy. The Economic Journal, 92(368), 825-848.

CSIROpedia. (2017). Earth Science and Resource Engineering. Retrieved from https://csiropedia.csiro.au/earth-science-and-resource-engineering-2009.

David, P. (1985). Clio and the Economics of QWERTY. The American Economic Review, 75(2), 332-7.

David, P. \& Wright, G. (1997). Increasing Returns and the Genesis of American Resource Abundance. Industrial \& Corporate Change, 6(2), 203-45.

Dean, J. (2018). Characterising the Enabling sector for Australia's Resource Industries. Unpublished paper.

De Ferranti, D., Perry, G. E., Lederman, D., \& Maloney, W. F. (2002). From Natural Resources to the Knowledge Economy. Washington DC: IBRD. 
Dietrichs, E. (1995). Adopting a 'High-Tech' Policy in a 'Low-Tech' Industry: The Case of Aquaculture (Report No. 2). Oslo: STEP.

Dosi, G. (1988). Procedures, and Microeconomic Effects of Innovation. Journal of Economic Literature, 26(3), 1120-71.

Engen, O. A. (2002). Rhetoric and Realities. The NORSOK programme and Technical and Organisational Change in the Norwegian Petroleum Industrial Complex (Unpublished doctoral dissertation). University of Bergen, Bergen.

Engen, O. A. (2009). The Development of the Norwegian Petroleum Innovation System: A Historical Overview. In J. Fagerberg, D. C. Mowery, \& B. Verspagen (Eds.), Innovation, Path Dependency and Policy. The Norwegian Case (pp. 179-207). Oxford: Oxford University Press.

Food and Agriculture Organization of the United Nations (2013). Fisheries and aquaculture Department. Fishery and Aquaculture Country Profiles. The Kingdom of Norway. Retrieved from http://www.fao.org/fishery/facp/NOR/en. May 2013

Fisheries Research and Development Corporation (FRDC). (2010). Working Together: The National Fishing and Aquaculture RD\&E Strategy 2010. Canberra: FRDC.

Fleming, G., Merrett, D. \& Ville, S. (2004). The Big End of Town: Big Business and Corporate Leadership in Twentieth-Century Australia. Cambridge: Cambridge University Press.

Fluor (2018) Projects: Bass Strait Additional Oil Drilling Facilities. http://www.fluor.com/projects/offshore-onshore-engineering-procurement accessed 9 April 2018 
Gulbrandsen, M. \& Nerdrum, 1. (2009). Public Sector Research and Industrial Innovation in Norwy: A Historical perspective. In J. Fagerberg, B. Verspachen, \& D. Mowery (Eds.), Innovation, path dependency and policy: The Norwegian case (pp.61-88). Oxford: Oxford University Press.

Gylafson, T. (2001). Natural resources, education and economic development. European Economic Review, 45(4), 847-59.

Hanisch, T.J. and Nerheim, G. (1992). Fra vantro til overmot. Norsk oljehistorie bd.1.[From disbelief to bravado. Norwegian oil history volume 1]. Norsk petrolumsforening, Oslo.

Harrison, A. (2006). The Companion to Tasmania History: Aquaculture. University of Tasmania. http://www.utas.edu.au/library/companion_to_tasmanian_history/A/Aquaculture. $\underline{\text { htm }}$ accessed 9 April 2018

Herrigel, G. \& Zeitlin, J. (2010). Inter-firm Relations in Global Manufacturing: Disintegrated production and Its Globalization. In G. Herrigel (Ed.), Manufacturing Possibilities. Creative Action and Industrial Recomposition in the United States, Germany and Japan. Oxford: Oxford University Press.

Johannessen, F.E., Rønning, A. and Sandvik, P.T. (2005). Nasjonal kontroll og industriell fornyelse. Hydro 1945-1977 [National control and industrial renewal. Hydro 1945-1977]. Pax, Oslo.

Katz, Jorge, and Michiko Iizuka (2012) "Natural Resource Industries,? Tragedy of the Commons? and the Case of Chilean Salmon Farming." Institutions and Economies 3.2 (2012) Johns, R. K. (Ed.). (1976). History and role of government Geological Surveys in Australia. Canberra: AB James, Govt. printer. 
Laestadius, S. \& Noor, C. (2010). The disequilibrium path in natural resource economics. Stockholm: KTH Royal Institute of Technology.

Landes, D. (2003). The unbound Prometheus: Technical change and industrial development in Western Europe from 1750 to present (revised ed.). New York: Cambridge University Press.

Lloyd C., Metzer, J. \& Sutch, R. (Eds.). (2013). Settler Economies in World History. Leiden: Brill.

Marín, A. and S. Petralia (2018). Sources and contexts of inter-industry differences in technological opportunities: the cases of Argentina and Brazil. Innovation and Development, $8: 1,29-57$

Marin, A. and Smith, A. (2011). Towards a framework for analysing transformation in Natural Resource-based industries in Latin-America: The role of alternatives. Retrieved from http://nrpathways.wix.com/home.

Marin, A., Navas-Aleman, L. \& Perez, C. (2015). Natural Resource Industries as a Platform for the Development of Knowledge Intensive Industries. Tijdschrift Voor Economische en Sociale Geografie. 106(2), 154-168.

Mehlum, H., Moene, K. and Torvik, R. (2006). Institutions and the resource curse, Economic Journal 116(508), 1-20.

Mellbye, C., Fjose, S. \& Jakobsen, E. W. (2012). Internasjonalisering av norsk offshoreleverandфrindustri [Internationalisation of Norwegian offshore supply industry], Oslo: Menon Report. 
Morris, M., Kaplinsky, R. \& Kaplan, D. (2012). One thing leads to another- Commodities, linkages and industrial development. Resources Policy, 37(4), 408-416.

Mowery, D.C \& Rosenberg, N. (1989). Technology and pursuit of economic growth.

Cambridge: Cambridge University Press.

Ministry of Petroleum and Energy. (2017). Norway's petroleum history. Retrieved from http://www.norskpetroleum.no/en/framework/norways-petroleum-history.

Murray, R. (2002). Weeks, Lewis George (1893-1977). Australian Dictionary of Biography, 16.

Norskpetroleum.no (2017). [Website by Norwegian Ministry of Petroleum and Energy \& Norwegian Petroleum Directorate]. Retrieved from http://www.norskpetroleum.no/en/economy/governments-revenues/. 30.11.2017.

Norwegian Research Council. 2017. Det norske forsknings- og innovasjonssystemet statistikk og indikatorer 2017 [The Norwegian research and innovation system: Statistics and indicators 2017]. Oslo: Norwegian Research Council.

OECD. (2010). Globalisation in Fisheries and Aquaculture: Opportunities and Challenges. Paris: OECD.

OECD. Stat (2018). 'Level of GDP per capita and productivity'. https://stats.oecd.org/index.aspx?DataSetCode=PDB_LV accessed 30 April 2018

Olsen, O. E. \& Sejersted, F. (Eds.). (1997). Oljevirksomheten som teknologiutviklingsprosjekt [Oil sector as technology development project]. Oslo: Ad Notam Gyldendal.

O’Rourke, K. H. \& Williamson, J. G. (1999). Globalization and History. Cambridge, MA: MIT Press. 
Parliament of Australia. (1998). A sea of indifference: Australian industry participation in the North West Shelf project. Canberra: House of Representatives Standing Committee on Industry, Science and Technology.

Pol, E., Carroll, P. \& Robertson, P. (2002). A new typology for economic sectors with a view to policy implications. Economics of Innovation and New Technology, 11(1), 61-76.

Pollard, S. (1982). Peaceful Conquest, the Industrialization of Europe 1760-1970. London: Oxford University Press.

Prebisch, R. (1950). The Economic Development of Latin America and its Principal Problems. United Nations: New York.

Regjeringen. (2005). The Petroleum Sector - Norway's largest industry. Retrieved from https://www.regjeringen.no.

Richardsen, R. and Bull-Berg, H. (2016). Nasjonal betydning av sjømatnæringen. En verdiskapingsanalyse med data fra 2014 [National significance of the sea food industry. A value added analysis using data from 2014. Sintef Report A27705, Trondheim.

Ryggvik, H. (2000). Norsk oljevirksomhet mellom det nasjonale og det internasjonale. En studie av selskapsstruktur og internasjonalisering [Norwegian oil sector between the national and the international. A study of firm structure and internationalisation] (Unpublished doctoral dissertation). University of Oslo, Oslo.

Ryggvik, H. (2013). Building a skilled national offshore oil industry: The Norwegian experience. Oslo: NHO.

Restad Energy (2017), Internasjonal omsetning fra norske oljeselskaper, Rapport til Olje- og energidepartementet. 31. Oktober 2017. 
Sachs, J. D. \& Warner, A. M. (1995). Natural resource abundance and economic growth. (working paper no. 5398). Cambridge, MA: National Bureau of Economic Research.

Schedvin, C. B. (1990). Staples and regions of Pax Brittanica. Economic History Review, 43(4), 533-59.

Schrobback, P., Pascoe, S., \& Coglan, L. (2014). History, status and future of Australia's native Sydney rock oyster industry. Aquatic Living Resources, 27(3-4), 153-65.

Schwach, V. (2000). Havet, fisken og vitenskapen. Fra fiskeriunders $\phi$ kelser til havforskningsinstitutt 1860-2000 [Ocean, fish and science. The Norwegian Institute of Marine Research 1860-2000]. Bergen: Ocean Research Institute.

Scott-Kemis, D. (2013). How about those METS? Leveraging Australia's Mining Equipment, Technology and Services Sector. Forrest ACT: Minerals Council of Australia.

Sejersted, F. \& Olsen, O. E. (1997). Oljevirksomheten som teknologiutviklingsprosjekt. Perspektiver på utviklingen av det oljeteknologiske systemet på norsk kontinentalsokkel [Oil sector as a technology development project. Perspectives on the development of the oil technological system on the Norwegian Shelf]. Oslo: Ad Notam Gyldendal.

Simensen, E.O. and Thune T.M (2018). Innovation in the petroleum value chain and the role of supply companies in supporting innovation. In T.M. Thune, O.A. Engen, and O. Wicken, eds Petroleum Industry Transformations. Lessons from Norway and Beyond. London: Routledge.

Singer, H. W. (1950). The Distribution of Gains Between Investing and Borrowing Countries. American Economic Review, 40 (2), 473-85. 
SINTEF 2010, Regional verdiskaping i norsk sjфmatncering. [Regional value creation in Norwegian sea food industry], Report SINTEF Fiskeri og havbruk.

Smith, K. H. (2007). Innovation and Growth in Resource-Based Economies, Competing from Australia (Project paper no. 3). Melbourne: Committee for Economic Development of Australia.

Smith, K. and Wicken, O. (2016, February). Resource-based Growth in Small Open Economies: Towards a Theory. Paper presented at the Asia Pacific Economic and Business History Conference, Adelaide.

Statistics Norway (2017). Aquaculture. Retrieved from https://www.ssb.no/en/iord-skog-jaktog-fiskeri/statistikker/fiskeoppdrett, Oslo

Statistics Norway 2017b. Fiskeoppdrett - I Noreg og i verda. Frå attåtnæring til milliardindustri, [Aquaculture - in Norway and the world. From additional income to large scale industry]. Samfunnsspeilet 1/2017, Oslo 13.2.1017

Stortinget. 1974. Petroleumsvirksomhetens plass i det norske samfunn (White Paper no. 25). Oslo: Ministry of Finance.

Tanriverdi, H. \& Venkatraman, N. (2005). Knowledge relatedness and the performance of multibusiness firms. Strategic Management Journal, 26(2), 97-119.

Tasmanian Atlantic Salmon (2007). History. http://tasmaniansalmon.com.au/consumer/about/history.html Thurtell, D. (Ed.). (2017). Resources and Energy Overview. Canberra: Department of Industry, Innovation and Science. 
United Nations Development Programme, Human Development Reports (2016). Table 1: Human Development Index and its components. http://hdr.undp.org/en/composite/HDI accessed 30 April 2018.

Ville, S. \& Wicken, O. (2013). The Dynamics of Resource-Based Economic Development: Evidence from Australia and Norway. Industrial and Corporate Change, 22(5), 1341-71.

Ville, S. \& Wicken, O. (2015). The institutional foundations of natural resource based knowledge economies. In M. Badía-Miró, V. Pinilla \& H. Willebald (Eds.), Natural Resources and Economic Growth: Learning from History (pp. 294-312). Abingdon: Routledge.

Wicken, O. (2016). Industrial Diversification Processes and Strategies in an Oil Economy: Norway. In S. Mahroum \& Al-Saleh Yasser (Eds.), Economic Diversification Policies in Natural Resource Rich Economies (pp. 295-323). London: Routledge.

Woodside Petroleum. (2017). Global interests. Retrieved from http://www.woodside.com.au/About-Us/Pages/Global-Interests.aspx\#.WIAhG2U4I24.

World Bank. Knowledge Economy Index.

https://datasource.kapsarc.org/explore/dataset/knowledge-economy-index-world-bank2012/table/?refine.time_period=2012\&refine.indicator=Knowledge+economy+rank\&sort=obs_value accessed 30 April 2018

Wright, G. (1990). The origins of American industrial success, 1879-1940. American Economic Review, 80(4), 651-68.

Wright, G. \& Czelusta, J. (2004). Why Economies Slow: The Myth of the Resource Curse. Challenge, 47(2), 6-38. 
Wrigley, A. (1988). Continuity, Chance and Change: The Character of the Industrial Revolution in England. Cambridge: Cambridge University Press.

Zimmermann, E (1933/1951), World Resources and Industries: A Functional Appraisal of the Availability of Agricultural and Industrial Resources (1933) New York: Harper \& Brothers/ World Resources and Industries, 2nd revised ed. (1951) New York: Harper \& Brothers. 